Volume 6 Nomor 1, Februari 2021, halaman 97 - 108.

\title{
Analisis Teori Perkembangan Kognitif Piaget Pada Anak Usia 11 Tahun Di Brebes
}

\section{Piaget's Theory of Cognitive Development Analysis in 11 Year Olds in Brebes}

\author{
Nungki Anditiasari ${ }^{1}$, Nuriana Rachmani Dewi ${ }^{2}$ \\ ${ }^{1}$ Pascasarjana program studi matematika Universitas Negeri Semarang, Semarang, Indonesia, \\ nungkianditiasari@students.unnes.ac.id \\ ${ }^{2}$ Pascasarjana program studi matematika Universitas Negeri Semarang, Semarang, Indonesia, \\ nurianaramadan@mail.unnes.ac.id
}

\begin{abstract}
ABSTRAK
Penelitian ini bertujuan untuk mengetahui perkembangan kognitif anak usia 11 tahun dalam menyelesaikan operasional konkret menurut tahap perkembangan kognitif piaget yaitu : mengurutkan, klasifikasi, penalaran, pemahaman, konservasi, dan penghilangan sifat egosentrisme. Penelitian ini perlu dilakukan sebagai acuan pengajar dalam memberikan metode pembelajaran yang tepat yaitu dengan mengetahui sejauh mana kemampuan masing-masing anak didiknya dilihat dari kemampuan kognitifnya. Subjek penelitian ini berjumlah tujuh anak usia kisaran 11 tahun. Pengumpulan data dilakukan dengan wawancara, tes dan dokumentasi. Analisis data dilakukan dengan metode studi kasus dengan melihat hasil dari aktivitas siswa dan dengan menarik kesimpulan. Berdasarkan hasil penelitian dari ke tujuh anak, terdapat 2 anak tidak dapat menyelesaikan beberapa tahap operasional konkret sesuai perkembangan kognitif piaget.
\end{abstract}

Kata Kunci : kesulitan matematika, studi kasus, penyelesaian soal cerita.

\begin{abstract}
This study aims to determine the cognitive development of children aged 11 years in completing concrete operations according to the stages of Piaget's cognitive development, namely: sorting, classification, reasoning, understanding, conservation, and eliminating egocentrism. This research needs to be carried out as a reference for teachers in providing appropriate learning methods, namely by knowing the extent to which the abilities of each student are seen from their cognitive abilities. The subjects of this study were seven children aged 11 years. The data was collected by means of interviews, tests and documentation. Data analysis was carried out by using the case study method by looking at the results of student activities and by drawing conclusions. Based on the research results of the seven children, there were 2 children who were unable to complete several concrete operational stages according to Piaget's cognitive development.
\end{abstract}

Keywords: math difficulties, case studies, solving story problems.

How to Cite: Anditiasari, N., Dewi, N. R. Mathline: Jurnal Matematika dan Pendidikan Matematika. Vol. 6 No. 1, 97 - 108.

DOI: https://doi.org/10.31943/mathline.v6i1.177 


\section{PENDAHULUAN}

Perkembangan fisik, emosi, sosial, kognitif, bahasa, serta berbicara merupakan tahapan perkembangan anak usia 7-12 tahun. Sejalan dengan pendapat Pardede (2020) dalam penelitiannya bahwa aspek perkembangan anak usia 7-12 tahun meliputi perkembangan bahasa fisik, kognitiff emosi serta sosial. Setiap bertambahnya usia anak, perkembangan yang dialami anak juga akan berbeda-beda mengikuti pertambahan usianya. Seperti yang dikatakan Farida (2018) dalam penelitiannya bahwa setiap anak mempunyai ciri khas dan keunikan sendiri-sendiri tidak dapat disamakan satu dengan yang lainnya.

Factor genetik dan lingkungan merupakan salah satu factor yang mempengaruhi perkembangan anak. Seperti yang dikatakan Latifa (2017) pada penelitiannya bahwa perkembangan anak dipengaruhi oleh factor genetik dan lingkungan. Pada usia 11 tahun perkembangan masing-masing anak juga belum tentu akan sama antara satu anak dengan anak yang lainnya. Orangtua dan guru sebaiknya memperhatikan perkembangan anak, karena hal tersebut menjadi sesuatu yang penting untuk kehidupan mereka pada masa yang akan datang. Hal ini seperti yang dikatakan Suhono dan Utama (2017) dalam penelitiannya mengatakan bahwa pertumbuhan dan perkembangan peserta didik menjadi perhatian orangtua dan pengajar sebagai teladan yang baik. Setiap anak usia $7-12$ tahun dalam perkembangan fisik, emosi, sosial, kognitif, bahasa, serta berbicara berbeda - beda satu dengan yang lainnya.

Menurut Ahmad (2012) kognitif sebagai perkembangan anak dalam menghubungkan, menilai dan mempertimbangkan suatu kejadian. Tingkat kecerdasan merupakan perwujudan proses kognitif pada anak yang ditunjukkan dengan minat dan gagasan dalam belajar. Seperti penelitian yang dilakukan Karim dan Wifroh (2014) bahwa kecerdasan merupakan perwujudan dari perkembangan kognitif siswa. Perkembangan kognitif yang dimiliki oleh anak diharapkan nantinya berguna dalam mempelajari informasi yang ada disekelilingnya, untuk kelangsungan hidup anak kedepannya dan bermanfaat untuk orang lain.

Menurut Jarvis et al. (2007) anak usia 7-12 tahun dalam teori kognitif piaget masuk dalam tahap operasional konkret. Pada tahap ini, anak sudah mampu dalam menggunakan operasi dan logikanya, akan tetapi untuk objek yang nyata saja. Kecenderungan terhadap animism dan articialisme telah hilang. Sifat Egoisnya juga sudah berkurang dan dalam hal mengkonservasi sudah lebih baik. Dalam menyelesaikan permasalahan logika anak tahap operasional konkret mengalami kesulitan jika tidak menggunakan objek secara langsung. Dalam penelitiannya Juwantara (2019) juga mengatakan anak akan mengalami kesulitan 
dalam menyelesaikan maslah ketika anak menghadapi permasalahan yang abstrak tidak nyata.

Kartadinata (2003) menyatakan bahwa otak pada anak akan terus tumbuh dan berkembang sesuai dengan usianya, imajinasi yang dimiliki anak merupakan salah satu factor dalam membentuk jaringan dan perkembangan otak pada anak. Pada usia 7 - 12 tahun kemampuan kognitif anak berkembang menjadi berfikir konkret dan diterima oleh akal. Menurut Piaget hal tersebut dinamakan dalam perkembangan kognitif anak tahap operasional konkret yang behubungan dengan hal yang nyata.

Menurut Piaget (2002) sikap yang fleksibel merupakan bentuk penalaran perkembangan pada anak usia 7-12 tahun. Ketika anak berkomunikasi dengan orang lain mereka akan memahami bahwa sesuatu yang benar atau salah bukan menjadi suatu acuan yang pasti untuk digunakan. Teori kognitif Piaget perlu diterapkan karena sistem pendidikan sekarang lebih menekankan pada kemampuan kognitif anak, oleh karena itu peneliti ingin mengetahui perkembangan kognitif pada anak usia 11 tahun yang ditinjau dari aspek teori belajar kognitif piaget tahap operasional konkret yaitu : mengurutkan, klasifikasi, penalaran, pemahaman, konservasi, dan penghilangan sifat egosentrisme.

\section{METODE PENELITIAN}

Metode penelitian ini adalah metode penelitian kualitatif yang bertujuan untuk mendeskripsikan perkembangan kognitif anak usia 11 tahun dalam memasuki tahap operasional konkret menurut teori kognitif piaget yang terdiri dari tahap konservasi, tahap reversibility, tahap susbtansi, tahap menganalisis, tahap mengurutkan, tahap klasifikasi, tahap decentring, dan tahap penghilang sifat egoisentrisme. Tekhnik pengumpulan data dalam penelitian ini yaitu observasi dan wawancara. Instrumen yang digunakan adalah menggunakan media yang disediakan oleh peneliti seperti gelas, pulpen snack dan uang.

Waktu dan tempat penelitian dilakukan di Bimbingan Belajar Cerdas Ceria di jalan Cisanggarung Timur Kaligangsa Wetan Brebes setelah proses belajar mengajar selesai tepatnya pada tanggal 26 november 2020. Dari keseluruhan siswa diambil hanya 7 anak usia 11 tahun kelas 5 SD. Metode pengumpulan data menggunakan metode observasi dan dokumentasi.

\section{HASIL PENELITIAN DAN PEMBAHASAN}

Subjek A, B, C, D, E, F, dan G merupakan anak kelas 5 SD berusia 11 tahun. Dalam penelitian ini peneliti melakukan pengujian kepada anak-anak usia 11 tahun. Pengujian 
yang dilakukan adalah tahap-tahap operasional konkret menurut teori kognitif piaget pada usia 11 tahun. Tahap operasional konkret menurut Piaget terdiri dari tahap konservasi, tahap reversibility, tahap substansi, tahap menganalisis, tahap mengurutkan, tahap klasifikasi, tahap decentring, dan tahap penghilang sifat egoisentrisme.

Tabel 1. Persamaan dan perbedaan tahapan operasional konkret dari ke 7 anak usia 11 tahun

\begin{tabular}{|c|c|c|c|c|c|c|c|c|c|}
\hline \multirow[t]{2}{*}{ No } & \multirow{2}{*}{\multicolumn{2}{|c|}{$\begin{array}{c}\text { Tahapan Operasional } \\
\text { Konkret }\end{array}$}} & \multicolumn{7}{|c|}{ Anak usia 11 tahun } \\
\hline & & & $\mathbf{A}$ & B & $\mathbf{C}$ & $\mathbf{D}$ & $\mathbf{E}$ & $\mathbf{F}$ & $\mathbf{G}$ \\
\hline 1 & Konservasi & & $\sqrt{ }$ & $\sqrt{ }$ & $\sqrt{ }$ & $\sqrt{ }$ & $\sqrt{ }$ & $\sqrt{ }$ & $\sqrt{ }$ \\
\hline 2 & Reversibility & & - & $\sqrt{ }$ & $\sqrt{ }$ & $\sqrt{ }$ & $\sqrt{ }$ & $\sqrt{ }$ & $\sqrt{ }$ \\
\hline 3 & Substansi & & - & $\sqrt{ }$ & - & $\sqrt{ }$ & $\sqrt{ }$ & $\sqrt{ }$ & $\sqrt{ }$ \\
\hline 4 & Menganalisis & & $\sqrt{ }$ & $\sqrt{ }$ & $\sqrt{ }$ & $\sqrt{ }$ & $\sqrt{ }$ & $\sqrt{ }$ & $\sqrt{ }$ \\
\hline 5 & Mengurutkan & & $\sqrt{ }$ & $\sqrt{ }$ & $\sqrt{ }$ & $\sqrt{ }$ & $\sqrt{ }$ & $\sqrt{ }$ & $\sqrt{ }$ \\
\hline 6 & Klasifikasi & & $\sqrt{ }$ & $\sqrt{ }$ & $\sqrt{ }$ & $\sqrt{ }$ & $\sqrt{ }$ & $\sqrt{ }$ & $\sqrt{ }$ \\
\hline 7 & Decentring & & - & - & - & - & - & - & - \\
\hline 8 & Penghilangan & Sifat & $\sqrt{ }$ & $\sqrt{ }$ & $\sqrt{ }$ & $\sqrt{ }$ & $\sqrt{ }$ & $\sqrt{ }$ & $\sqrt{ }$ \\
\hline & Egosentrisme & & & & & & & & \\
\hline
\end{tabular}

\section{Tahap Konservasi}

Konservasi yang dimaksud disini adalah karakteristik dari suatu objek akan tetap sama walaupun objek tersebut berubah bentuk. Menurut piaget, panjang, kuantitas dan jumlah suatu benda pada tahapan konservasi tidak ada hubungannya dengan aturan atau perwujudan dari benda tersebut. Tahap perkembangan operasional konkret ini siswa diberikan permasalahan tentang konservasi volume air. Volume air akan tetap sama meskipun air tersebut dimasukkan ke dalam wadah yang bentuknya berbeda
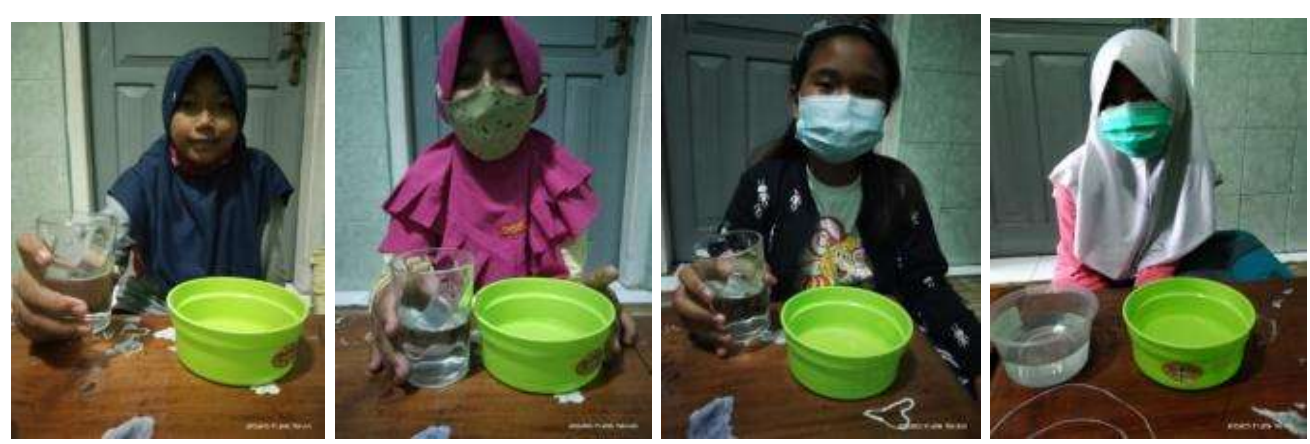

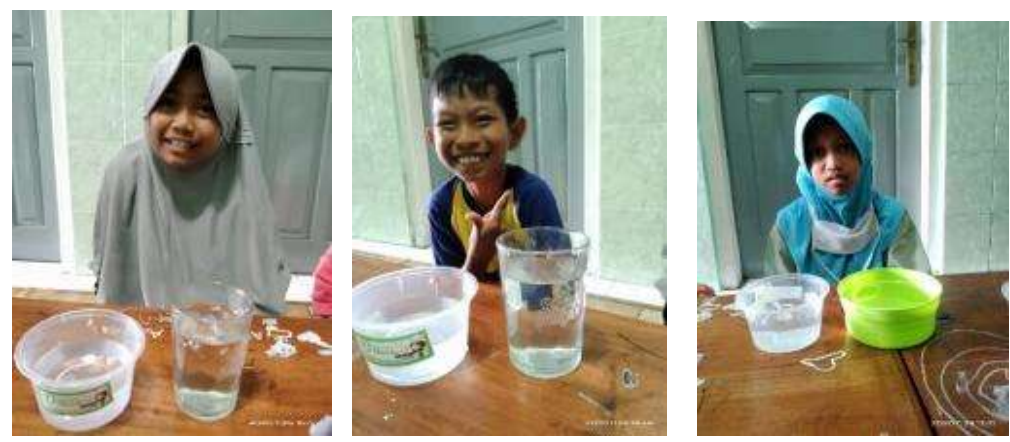

\section{Gambar 1. Pengamatan Pada Anak yang Sedang Memahami konsentrasi air}

Pada gambar 1 di atas kegiatan anak sedang memahami konservasi volume air. Dalam memahami konservasi volume air, ke 7 anak mempunyai jawaban yang sama yaitu jika 2 wadah air yang mempunyai volume sama dan ditempatkan di wadah yang sama, kemudian salah satu air dipindahkan ke wadah yang berbeda konservasi volume air juga akan sama. Ini terlihat ke 7 anak tersebut sudah memahami dengan baik tahapan konservasi volume air. Hal ini sejalan dengan penelitian Mu'min (2013) bahwa volume susu yang tadinya berada digelas yang gendut kemudian dituangkan digelas yang ramping akan mempunyai volume yang sama, akan tetapi berbeda volumenya jika jumlah susu yang dituangkan sengaja ditambahkan.

\section{Tahap Reversibility}

Pada tahap reversibility Piaget mengatakan bahwa pada tahapan ini anak mulai memahami benda atau jumlah dapat diubah, perubahan tersebut dapat kembali ke bentuk atau keadaan semula. Pada tahap operasional konkret anak usia 7 - 12 tahun kemampuan dalam mengoperasikan soal matematika jauh lebih baik. Peneliti mencoba memberikan soal yang berkaitan dengan tahap reversibility.

$$
\begin{gathered}
8+8=16 \\
16-\ldots \ldots=8
\end{gathered}
$$

\section{Gambar 2. Contoh Operasi Matematika Tahap Reversibility}

Gambar 2 merupakan bentuk soal matematika pada tahap reversibility. Untuk anak usia SD pasti dengan mudah untuk menjawab 8+8, akan tetapi jika diberikan soal 16 dikurangi berapa agar hasilnya sama dengan 8 tidak semua bisa menjawab. Untuk anak usia 11 tahun dimana pada usia tersebut kemampuan matematika sudah semakin baik dalam menjawab Ke 7 anak yang mencoba mengerjakan soal tersebut tidak semuanya bisa menjawab dengan benar, ada anak yang masih salah dalam menjawabnya. bisa dilihat 
bahwa tidak semua anak pada usia 11 tahun menguasai operasi matematika dasar dengan baik.

Sejalan dengan penelitian yang dilakukan Juwantara (2019) anak akan mengalami kesulitan dalam menjawab soal matematika jika diberikan soal dalam bentuk dan angka yang berbeda. Hal ini juga sejalan dengan penelitian Anditiasari (2020) menyatakan bahwa siswa akan mengalami kesulitan dalam memahami konsep matematika saat mengerjakan soal.

\section{Tahap substansi}

Pada tahap operasional konkret selanjutnya yaitu dalam memahami konsep substansi. Disini peneliti menggunakan 2 wadah yang berisi snack yang awalnya berjumlah sama banyak. Jika anak dalam tahap operasional konkret pasti akan dengan mudah mengetahui bahwa bentuknya masih tetap biskuit dan berat biscuit tersebut adalah sama. Seperti yang dikatakan Mu'min (2013) dalam penelitiannya hampir semua anak pada tahap operasional konkret memiliki kemampuan mempertahankan apa yang diketahui tentang bentuk, berat dan ukuran benda yang diamati akan tetap sama walaupun bentuk luarnya sudah berubah.
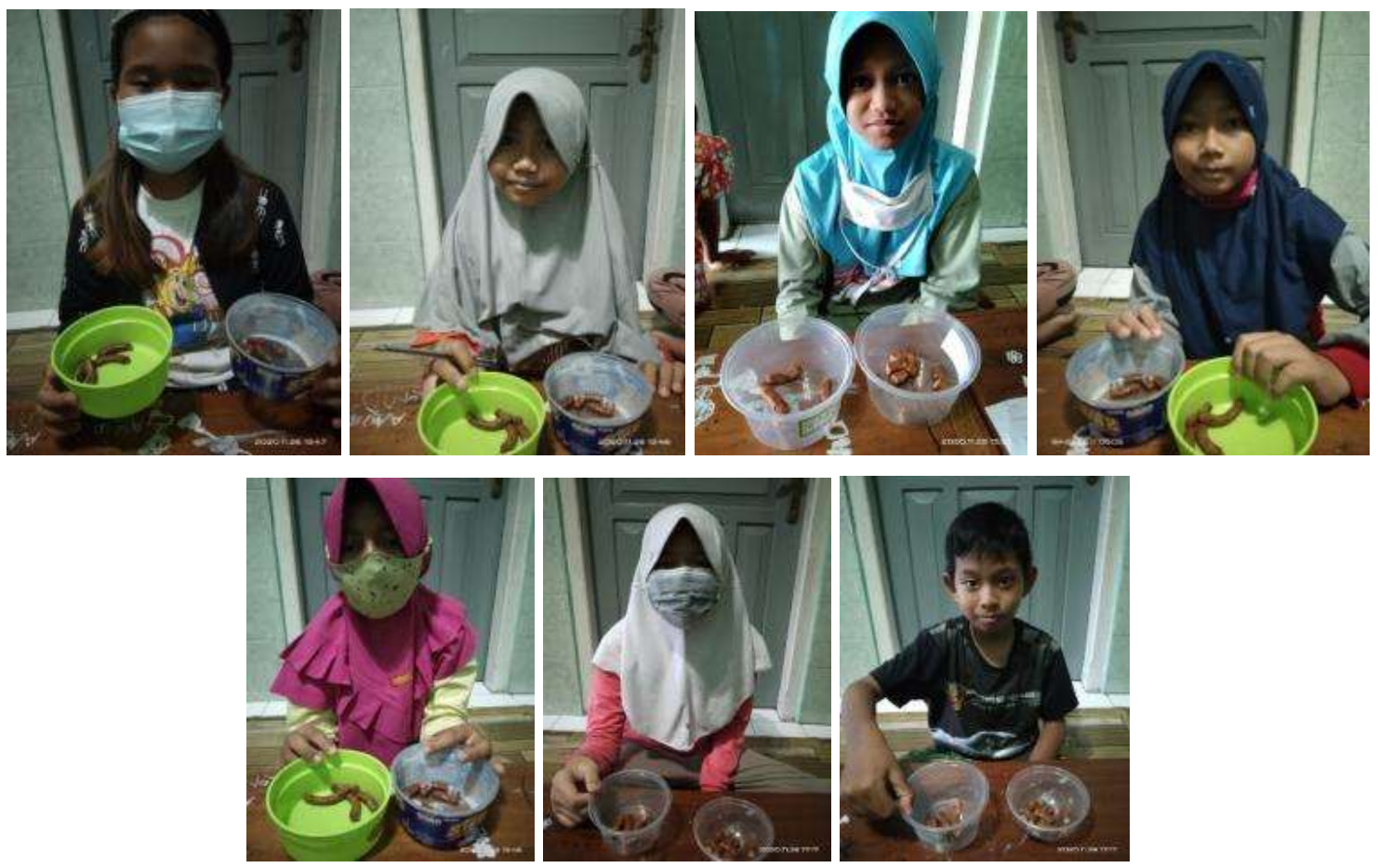

\section{Gambar 3. Pengamatan Pada Anak yang sedang Memahami Konsep Substansi}

Pada gambar 3 terlihat anak sedang memahami permasalahan yang diberikan peneliti. Kemudian peneliti memotong-motong biscuit pada salah satu wadah, setelah itu peneliti mencoba menanyakan kembali apakah sekarang bentuk dan beratnya masih sama dengan yang belum dipotong-potong. Ke 7 anak tersebut memiliki jawaban yang beragam, 
5 anak menjawab bentuknya masih biskuit akan tetapi beratnya tidak sama, dan 2 anak yang lain menjawab bentuknya masih sama karena walaupun sudah dipotong-potong dan beratnya berbeda. Jawaban yang beragam menunjukkan bahwa anak dalam kemampuan daya ingat dan konsep substansi tidak sama walaupun usia dan tingkat sekolah mereka sama.

\section{Tahap Menganalisis}

Pada usia 11 tahun anak biasanya sudah dapat menganalisis sesuatu. Anwar (2017) mengatakan bahwa anak sudah dapat menganalisis, mengkontraskan dan menghubungkan teori dengan fakta untuk menarik kesimpulan. Peneliti kemudian memberikan pertanyaan seputar gelas yaitu apa bahan dari gelas, fungsi gelas, dan jika gelas tersebut terjatuh apa yang akan terjadi.
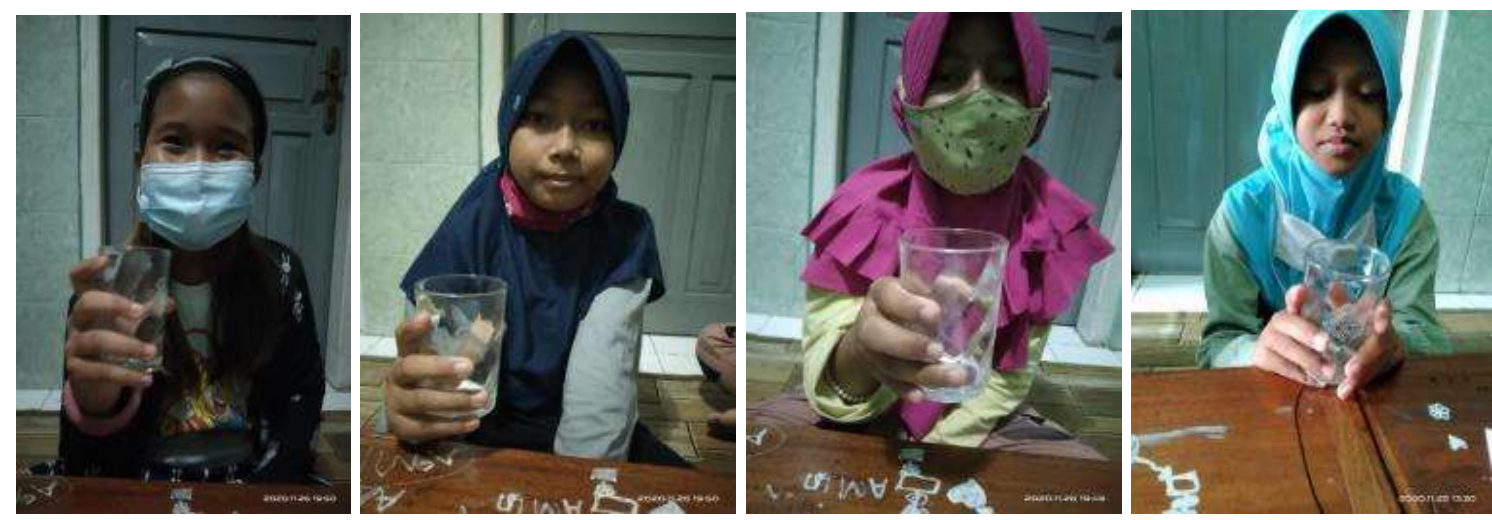

Gambar 4. Pengamatan Pada Anak yang sedang Menganalisis

Pada gambar 4 anak sedang memahami tentang gelas. Tidak semua anak sempat untuk di dokumentasikan, akan tetapi dari ke tujuh anak memiliki jawaban yang hampir sama akan tetapi kurang tepat. Hampir semua anak menjawab bahwa gelas terbuat dari kaca dan berfungsi untuk minum. Jawaban yang tepat seharusnya adalah gelas terbuat dari liquid sand atau pasir cair dan fungsi gelas itu sendiri sebagai tempat menampung air untuk diminum. Jika gelas tersebut terjatuh apa yang akan terjadi, semua anak menjawab dengan benar yaitu akan pecah. Dapat dikatakan ke 7 anak usia 11 tahun menjawab dengan benar dan dapat menganalisis, mengkontraskan dan menghubungkan teori dengan fakta untuk menarik kesimpulan dengan baik. Sama seperti penelitian yang dilakukan Bujuri (2018) bahwa setiap anak memiliki kemampuan yang berbeda baik dalam bernalar, memahami, menganalisis ataupun menghubungkan sesuatu untuk menarik kesimpulan. 


\section{Tahap Mengurutkan}

Pada usia 11 tahun anak biasanya sudah dapat menguasai konsep mengurutkan. Menurut Piaget pada tahap ini anak memiliki kemampuan dalam hal untuk mengurutkan objek menurut ukuran, bentuk, atau ciri yang lainnya. Ke 7 anak diminta untuk mengurutkan tinggi badan masing-masing dari ke 7 anak tersebut. Tanpa melakukan perlu berfikir lama Ke 7 anak dapat dengan mudah mengetahui siapa anak yang paling tinggi dan menjawab dengan benar bahwa urutan dari yang paling tinggi ke rendah adalah anak D, B, C, A, F, E, dan G. Dapat dikatakan bahwa ke 7 anak tersebut sudah memahami dengan baik tahap mengurutkan suatu benda berdasarkan tinggi. Seperti penelitian yang dilakukan Mutiara dan Agustin (2017) bahwa anak - anak sebagian besar mampu dalam membandingkan dan mengurutkan suatu benda berdasarkan ukuran maupun bentuknya.

\section{Tahap Klasifikasi}

Pada usia 11 tahun anak biasanya sudah dapat menguasai konsep pengelompokkan. Menurut Santrock (2011) kemampuan untuk menyususn suatu objek berdasarkan panjang warna, berat dan lain sebagainya. Pada tahap ini anak diminta mengelompokkan warna pulpen yang sama, yaitu kelompok pulpen dengan warna merah, hijau, ungu, biru dan hitam

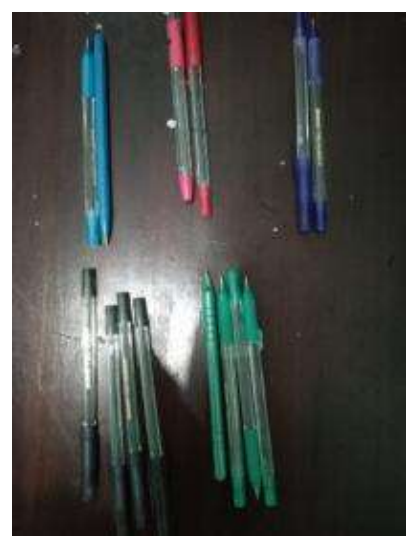

\section{Gambar 5. Hasil Pengelompokkan Warna yang dilakukan Siswa}

Pada gambar 5 terlihat anak dengan mudah mengelompokkan warna setiap pulpen sesuai dengan kesamaan warna yang dimiliki yaitu warna biru, merah. Ungu, hitam dan hijau. Dapat dikatakan ke 7 anak dalam operasional konkret tahap klasifikasi sudah terpenuhi. Sejalan dengan penelitian Arimbi et al. (2018) dalam menyusun suatu benda anak akan mengklasifikasikan benda tersebut sesuai dengan kesamaan yang dimiliki baik warna, panjang ataupun karakteristik lainnya. 


\section{Tahap Decentring (layak)}

Menurut Piaget pada tahap ini anak mulai mempertimbangkan beberapa aspek dari suatu permasalahan untuk dapat diselesaikan. Pada usia 11 tahun anak sudah dapat menggunakan penalarannya secara induktif. seperti penelitian yang dilakukan Sekar dan Adam (2014) bahwa penalaran induktif anak sekolah dasar akan berkembang seiring meningkatnya pengetahuan anak Penalaran secara induktif merupakan berfikir dengan melihat sesuatu secara umum kemudian menarik kesimpulannya secara khusus.

Pada tahap decentring peneliti meminta ke 7 anak tersebut untuk menjatuhkan buku, pulpen dan penghapus dan ketiga benda tersebut jatuh ke bawah secara bersama. Ketujuh anak tersebut menyimpulkan bahwa semua benda yang dijatuhkanbersama - sama pasti akan jatuh kebawah secara bersamaan . Padahal tidak semua benda jika dijatuhkan secara bersama - sama akan jatuh secara bersamaan, itu bisa disebabkan oleh massa setiap benda dan hambatan oleh udara yang menghalangi benda tersebut. Dapat dikatakan bahwa ke tujuh anak tersebut hanya dapat menggunakan penalaran secara induktif. Dalam penelitian Karim dan Wifroh (2014) mengatakan bahwa rendahnya aspek kognitif penalaran yang dimiliki oleh siswa.

\section{Tahap Penghilangan Sifat Egosentrisme}

Pada tahap terakhir yaitu tahap penghilangan sifat egosentrisme. Menurut Piaget penghilangan sifat egosentrisme merupakan ketidaktauan anak menilai suatu permasalahan dengan mementingkan kepentingannya sendiri dari sudut pandang orang lain, walaupun ketika oranglain mempunyai pendapat yang salah.
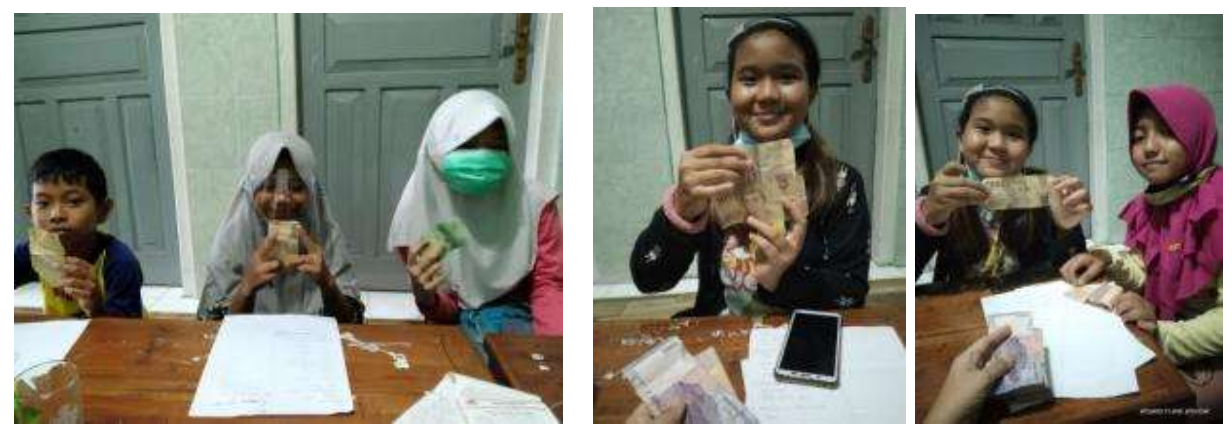

\section{Gambar 6. Pengamatan Pada Anak Yang Sedang Memahami Permasalahan} Tahap Penghilang Sifat Egosentrisme

Pada gambar 6 anak sedang memahami permasalahan tahap penghilang sifat egosentrisme. Disini peneliti memberikan permasalahan tentang pembagian uang Rp 5000, 00 jika dibagi kepada tiga anak, anak pertama Rp 3000,00 dan 2 anak yang lainnya 
masing-masing mendapat Rp 1000,00. Ke 7 anak tersebut menjawab serempak bahwa pembagian kurang tepat dikarenakan jumlahnya tidak sma banyak, mereka juga menjawab seharusnya dibagi menjadi 3 sama banyak. Terlihat bahwa sifat egosentrisme ke 7 anak tersebut sudah tidak ada seiring dengan perkembangan usia masing-masing anak. Seperti penelitian yang dilakukan oleh Alhaddad (2012) bahwa pada tahap operasional konkret sifat egoism anak sudah mulai berkurang, meraka sudah mau bermain bersama teman temannya, bertukar mainan dengan teman - temannya dan berbagi makanan secara adil.

\section{KESIMPULAN}

Hasil penelitian diatas dapat disimpulkan bahwa perkembangan kognitif 7 anak pada tahap operasional konkret yaitu usia 11 tahun berbeda-beda. Pada tahap operasional konkret konservasi ke 7 anak sudah memahami dengan baik tahapan konservasi volume air. Pada tahap substabsi terdapat 2 anak yang memiliki kemampuan daya ingat dan konsep substansinya kurang, sedangkan ke 5 anak yang lainnya memiliki kemampuan daya ingat dan konsep substansi yang baik.

Pada tahap operasional konkret menganalisis Dapat dikatakan ke 7 anak usia 11 tahun menjawab dengan benar dan dapat menganalisis, mengkontraskan dan menghubungkan teori dengan fakta untuk menarik kesimpulan dengan baik. Pada tahap operasional konkret mengurutkan sebagian besar anak sudah mampu melakukannya, dapat dikatakan anak-anak tersebut sesuai dengan perkembangan kognitif Piaget dalam tahap mengurutkan.

Pada operasional konkret tahap klasifikasi anak juga dapat mengklasifikasikan dengan baik benda-benda sesuai dengan karakteristiknya, hal ini bisa dikatakan anak secara perkembangan kognitif aspek klasifikasi sesuai dengan tahapannya. Untuk tahap decentring anak dengan mudah menyimpulkan sesuai dengan apa yang diamati saja, tidak melihat secara khusus karakteristik benda yang lainnya apakah sama dengan yang diamati.

Pada operasional tahap reversibility terdapat anak yang masih salah dalam menjawabnya. bisa disimpulkan bahwa tidak semua anak pada usia 11 tahun menguasai operasi matematika dasar dengan baik. Pada tahapan konservasi ke 7 anak sudah memahami dengan baik konsentrasi volume air. Terakhir adalah penghilangan sifat egosentrisme, pada tahap ini sifat egosentrisme ke 7 anak tersebut sudah tidak ada seiring dengan perkembangan usia masing-masing anak.

Pemahaman setiap tingkatan kemampuan kognitif anak usia 11 tahun yaitu pada tahap operasional konkret perlu diperhatikan baik pengajar maupun orangtua. Dalam hal 
ini pengajar dengan mudah mengetahui sejauh mana kemampuan masing-masing anak didiknya dilihat dari kemampuan kognitifnya. Selain itu baik pengajar dan orangtua diharapkan juga memberikan stimulus kepada anak agar kemampuan anak secara kognitif mencapai target sesuai tahap usia perkembangan kognitifnya.

\section{DAFTAR PUSTAKA}

Ahmad, S. (2012). Perkembangan Anak Usia Dini: Pengantar dalam Berbagai Aspek. Kencana Prenada Media Group.

Alhaddad, I. (2012). Penerapan Teori Perkembangan Mental Piaget Pada Konsep Kekekalan Panjang. Infinity Journal, 1(1), 31. https://doi.org/10.22460/infinity.v1i1.5

Anditiasari, N. (2020). Matematika Analysis Of Learning Difficulties Of Children With Special Needs In Completing Mathematical Story. Mathline: Jurnal Matematika Dan Pendidikan Matematika, 5, 183-194.

Anwar, C. (2017). Buku terlengkap teori-teori pendidikan klasik hingga kontemporer: Formula dan penerapannya dalam pembelajaran / Chairul Anwar. IRCiSoD.

Arimbi, Y. D., Saparahayuningsih, S., dan Ardina, M. (2018). Meningkatkan Perkembangan Kognitif Melalui Kegiatan Mind Mapping. Jurnal Ilmiah Potensia, $3(1), 64-71$.

Bujuri, D. A. (2018). Analisis Perkembangan Kognitif Anak Usia Dasar dan Implikasinya dalam Kegiatan Belajar Mengajar. LITERASI (Jurnal Ilmu Pendidikan), 9(1), 37. https://doi.org/10.21927/literasi.2018.9(1).37-50

Farida, F. (2018). Upaya Mengoptimalkan Perkembangan Anak Usia Dini. ThufuLA: Jurnal Inovasi Pendidikan Guru Raudhatul Athfal, 2(1), 1. https://doi.org/10.21043/thufula.v2i1.4263

Jarvis, M., Widowati, D. S., dan SPA-Teamwork. (2007). Teori-teori psikologi: pendekatan modern untuk memahami perilaku, perasaan dan pikiran manusia. Nusamedia.

Juwantara, R. A. (2019). Analisis Teori Perkembangan Kognitif Piaget pada Tahap Anak Usia Operasional Konkret 7-12 Tahun dalam Pembelajaran Matematika. Al-Adzka: Jurnal Ilmiah Pendidikan Guru Madrasah Ibtidaiyah, 9(1), 27. https://doi.org/10.18592/aladzkapgmi.v9i1.3011

Karim, M. B., dan Wifroh, S. H. (2014). Meningkatkan Perkembangan Kognitif Pada Anak Usia Dini Melalui Alat Permainan Edukatif. Jurnal Pendidikan Dan Pembelajaran Anak Usia Dini, 1(2), 103-113.

Kartadinata, S. (2003). Konseptualisasi Pendidikan Anak Usia Dini di Indonesia. Jurnal Ilmu Pendidikan.

Latifa, U. (2017). Aspek Perkembangan pada Anak Sekolah Dasar: Masalah dan Perkembangannya. Journal of Multidisciplinary Studies, 1(2), 185-196.

Mu'min, S. A. (2013). Teori Perkembangan Kognitif Jean Piaget. Jurnal Al-Ta'dib, 6(1).

Mutiara, S., dan Agustin, M. (2017). Profil Kompetensi Early Math Anak Usia 5-6 Tahun (Studi Deskriptif Pada Anak Usia 5-6 Tahun di TK Az-Zahra Kota Bandung). Golden Age: Jurnal Pendidikan Anak Usia Dini, 1(1), 59-65. https://doi.org/10.29313/ga.v1i1.2683

Pardede, J. A. (2020). Kesiapan Peningkatan Perkembangan Anak Usia Sekolah. OSFpreprints.

Piaget, J. (2002). Tingkat Perkembangan Kognitif. Gramedia.

Santrock, J. W. (2011). Masa perkembangan anak. In 1. Salemba Humanika. 
Sekar, L., dan Adam, P. (2014). Pengaruh Bermain Puzzle Video Game terhadap Kemampuan Penalaran Induktif pada Anak Usia Sekolah.

Suhono, dan Utama, F. (2017). Perkembangan Anak Usia Dini ( Perspektif Abdullah Nashih Ulwan Kajian Kitab Tarbiyyah Al-Aulad Fi Al-Islam ). Elemetary, 3, 107119. 